\title{
ANALISIS KESALAHAN SISWA DALAM MENYELESAIKAN SOAL CERITA PADA MATERI SISTEM PERSAMAAN LINEAR DUA VARIABEL BERDASARKAN KEMAMPUAN SISWA
}

\author{
Chika Yuliana $^{1}$, Sanusi $^{2}$, Swasti Maharani ${ }^{3}$ \\ Program Studi Pendidikan Matematika ${ }^{123}$, Universitas PGRI Madiun. Jalan \\ Setiabudi No. 85, Madiun \\ Email: chikassa0@gmail.com
}

\begin{abstract}
Abstrak
Tujuan penelitian ini adalah untuk menganalisis kesalahan siswa SMP dalam menyelesaikan soal cerita sistem persamaan linear dua variabel berdasarkan kemampuan tingkat tinggi, tingkat sedang dan tingkat rendah yang dimiliki siswa. Penelitian ini dilakukan pada siswa kelas VIII G SMP Negeri 1 Wungu, kemudian untuk menentukan subjeknya dilihat dari nilai hasil Ujian Tengah Semester (UTS) yang diperoleh dari guru matematika. Peneliti menggunakan 6 siswa untuk digunakan sebagai subjek.Teknik pengumpulan data dilakukan dengan metode tes, wawancara, dan dokumentasi. Teknik keabsahan data dilakukan dengan triangulasi waktu yaitu membandingkan data hasil tes dan wawancara tahap 1 dengan data hasil tes dan wawancara tahap 2. Pada penelitian ini analisis data menggunakan 3 tahap yaitu reduksi data, data display dan verivikasi/penarikan kesimpulan. Kesimpulan dari hasil penelitian ini adalah: 1) subjek berkemampuan tinggi tidak melakukan kesalahan dalam menyelesaikan soal. 2) subjek berkemampuan sedang memiliki tingkat kesalahan sedang, subjek tidak menuliskan kesimpulan dari soal yang telah dikerjakan. 3) subjek berkemampuan rendah memiliki tingkat kesalahan tinggi, subjek tidak dapat mentransformasikan soal, subjek tidak mengetahui prosedur yang dibutuhkan untuk menyelesaikan soal tersebut dan subjek tidak dapat menuliskan kesimpulan dari soal yang telah dikerjakan. Dari kesalahan-kesalahan yang dilakukan siswa, penelitian selanjutnya diharapkan dapat mengembangkan Lembar Kerja Siswa atau media pembelajaran yang menarik agar siswa paham dengan materi yang diajarkan untuk meminimalisir kesalahan yang dilakukan siswa.
\end{abstract}

Kata Kunci : Kesalahan, Soal Cerita, Kemampuan Siswa. 


\title{
STUDENT MISTAKE ANALYSIS IN SOLVING STORY PROBLEMS IN MATERIAL SYSTEM OF LINEAR EQUATIONS TWO VARIABLES BASED ON STUDENTS 'ABILITY
}

\begin{abstract}
Abstrak
The purpose of this study was to analyze the errors of junior high school students in the context of story problems, namely a linear variable of two variables of performance, medium and low levels of students. This study was conducted on VIII G class students of Wungu 1 Public Middle School, then to determine the lessons seen from the results of the Midterm Examination (UTS) obtained from the mathematics teacher. Researchers used 6 people to be used as subjects. Hidden data techniques were conducted using test methods, interviews, and documentation. Data validity technique is done by time triangulation that is comparing test results data and interview phase 1 with test results and interview stage 2 . In this study data analysis uses 3 stages, namely data reduction, data display and conclusion / conclusion conclusions. Conclusions from the results of this study are: 1) highly capable subjects do not make mistakes in the matter. 2) the subject is capable of using a moderate error level, an unwritten subject from the problem that has been done. 3) low-ability subject who has a high error rate, the subject cannot transform the problem, the subject does not know the procedure needed for the questions and cannot be used from the problem that has been done. Of the mistakes made by students, several things that make it possible to develop Student Worksheets or learning media that allow students to learn what students are doing.
\end{abstract}

Keywords: Error, Story Problem, Student Ability.

\section{PENDAHULUAN}

Pendidikan merupakan suatu bagian penting penentu kemajuan bangsa. Melalui pendidikan negara mampu melahirkan generasi-generasi penerus bangsa yang berkualitas untuk terus melanjutkan pembangunan negara dengan baik. Pendidikan pada dasarnya mengajarkan banyak hal mulai dari moral, etika, sains, agama dan lain-lain. Pendidikan juga mengajarkan bagaimana kita harus bersikap baik, bertanggung jawab, dan saling menghormati satu sama lain. Sesuai dengan UU RI No. 20, Tahun 2003 (dalam Moh. Suardi, 2012) pendidikan berfungsi mengembangkan kemampuan dan membentuk watak serta peradaban bangsa yang bermartabat dalam rangka mencerdaskan kehidupan bangsa. Di dalam kurikulum pendidikan baik pendidikan dasar sampai pendidikan tinggi ada muatan yang wajib di cantumkan, salah satunya adalah matematika. 
Matematika adalah pelajaran yang wajib di ikuti oleh siswa mulai dari tingkat Sekolah Dasar (SD), Sekolah Menengah Pertama (SMP) dan Sekolah Menengah Atas (SMA) untuk memberikan bekal kemampuan logis (Mulyadi, 2015). Matematika dapat diperoleh dalam pendidikan formal maupun non formal. Matematika pada pendidikan formal memiliki jam pelajaran yang lebih banyak dibandingkan dengan pelajaran yang lain karena matematika membutuhkan pemahaman yang lebih. Meski pelajaran matematika lebih banyak dijumpai daripada pelajaran lain, tetapi matematika masih dipandang pelajaran yang menyulitkan bagi siswa. Hal ini terjadi akibat kurangnya kemampuan siswa untuk belajar matematika. Munculnya penafsiran negatif ini menjadikan matematika dipandang pelajaran yang sangat sulit untuk dipelajari. Sehingga banyaknya jumlah jam pelajaran matematika tidak sebanding dengan prestasi belajar siswa. Rendahnya prestasi siswa ini ditunjukkan dengan rendahnya nilai Ujian Tengah Semester (UTS). Berdasarkan wawancara terhadap guru matematika kelas VIII SMP Negeri 1 Wungu pada saat Praktek Pengalaman Lapangan (PPL) yang dilaksanakan pada semester ganjil, ada beberapa materi yang diajarkan disekolah yang masih dianggap sulit oleh sebagian siswa salah satunya adalah materi sistem persamaan linear dua variabel.

Pada materi sistem persamaan linear dua variabel siswa diajarkan tentang membuat persamaan linear dua variabel, menentukan penyelesaian persamaan linear dua variabel, menyelesaikan masalah dalam kehidupan sehari-hari yang berkaitan dengan sistem persamaan linear dua variabel. Tapi kenyataannya masih banyak peserta didik yang masih kesulitan dalam mengerjakan soal sistem persamaan linear dua variabel dikarenakan masih kurangnya pemahaman konsep dalam mengidentifikasi suatu pernyataan pada sistem persamaan linear dua variabel.

Kesalahan siswa dalam menyelesaikan masalah dapat menjadi salah satu petunjuk untuk mengetahui sejauh mana pemahaman siswa terhadap materi yang diajarkan. Dengan adanya kesalahan-kesalahan tersebut perlu adanya identifikasi lebih lanjut dan dicari solusinya guna meningkatkan hasil belajar siswa. Dengan mengetahui tingkat kemampuan yang dimiliki siswa, guru dapat merencanakan solusi yang dapat digunakan untuk mengatasi kesalahan siswa dalam menyelesaikan soal cerita pada materi sistem persamaan linear dua variabel. 
Tujuan dari penelitian ini adalah adalah untuk menganalisis kesalahan siswa SMP dalam menyelesaikan soal cerita sistem persamaan linear dua variabel berdasarkan kemampuan tingkat tinggi, tingkat sedang dan tingkat rendah yang dimiliki siswa.

Kesalahan adalah penyimpangan terhadap hal yang diangggap benar atau penyimpangan terhadap prosedur yang telah ditentukan sebelumnya. Penyebab kesalahan yang dilakukan siswa dalam menyelesaikan soal cerita materi sistem persamaan linear dua variabel dapat dilihat dari berbagai hal, yaitu kesalahan procedural, kesalahan dalam mengorganisasikan data, kesalahan dalam menggunakan aturan dan kesalahan dalam menarik kesimpulan.

Soal cerita adalah soal matematika yang disajikan dengan kalimat-kalimat dalam bentuk cerita yang dikaitkan dengan kehidupan sehari-hari baik secara lisan maupun tulisan. Kemampuan siswa adalah kapasitas kesanggupan siswa untuk melakukan atau melaksanakan tugas dalam pembelajaran.

\section{METODE PENELITIAN}

Metode penelitian ini adalah metode deskriptif kualitatif. Penelitian dilakukan dengan pemberian tes dan wawancara terhadap subjek, sehingga data yang diperoleh tidak berbentuk angka. Data yang dihasilkan adalah deskriptif yang berupa kata-kata tertulis. Objek dalam penelitian ini yaitu kesalahan siswa dalam menyelesaikan soal cerita pada materi Sistem Persamaan Linear Dua Variabel. Teknik pengumulan data penelitian ini dengan menggunakan metode tes, wawancara.

Instrumen penelitian yang digunakan oleh peneliti sebagai alat pengumpul data adalah tes dan wawancara. Tes pada penelitian ini digunakan untuk mengukur tingkat kemampuan yang dimiliki siswa. Tes yang digunakan berupa soal uraian berjumlah 2 butir soal dengan tingkat mudah dan menengah. Sedangkan wawancara dalam penelitian ini menggunakan wawancara langsung untuk memperoleh informasi tentang kesalahan siswa dalam menyelesaikan soal tes yang berkaitan dengan materi sistem persamaan linear dua variabel yang diberikan.

Teknik analisis data yang digunakan dalam penelitian ini adalah analisis deskriptif, yaitu dengan cara mendeskripsikan data yang telah terkumpul. Data yang diperoleh dalam penelitian ini adalah data hasil tes dan hasil wawancara. Setelah data terkumpul dilakukan reduksi data yang bertujuan untuk memfokuskan data pada hal-hal yang diteliti. 


\section{HASIL DAN PEMBAHASAN}

\section{Subjek 1 Laki-Laki (Kategori Kemampuan Tinggi)}

Pada tahap memahami masalah subjek 1 mampu menerjemahkan dan mengidentifikasi bagian terpenting dalam permasalahan yaitu menentukan apa yang diketahui dan apa yang ditanyakan dalam permasalahan dengan benar. Dalam mengidentifikasi masalah Subjek 1 mampu mengetahui dan menyebutkan benda yang diketahui dari soal.Subjek 1 juga menjelaskan benda yang ada dalam soal dijadikan sebagai variabel.Sehingga Subjek termasuk golongan dapat mengenal bentuk dan menerjemahkan kalimat/masalah sistem persamaan linear dua variabel dengan benar.

Pada tahap perencanaan, Subjek 1 mampu merencanakan pemecahan masalah secara runtut dengan menuliskan setiap langkah penyelesaian yaitu diketahui, ditanya dan dijawab.Dalam memecahkan masalah Subjek 1 merencanakan menggunakan metode penyelesaian eliminasi dan substitusi.

Pada tahap pelaksanaan, Subjek 1 mampu melaksanakan setiap langkah penyelesaian sesuai dengan apa yang direncanakan. Subjek 1 melaksanakan langkah awal dengan menuliskan apa yang diketahui dan apa yang ditanyakan dari soal. Kemudian dilanjutkan dengan menuliskan permisalan dan model matematika dari permasalahan.Dalam melakukan perhitungan Subjek 1 mampu mengoperasikan penyelesaian menggunakan eliminasi dan substitusi.Sehingga dapat menentukan nilai $\mathrm{x}$ dan nilai y dengan benar.

Pada tahap melihat kembali, Subjek 1 menuliskan penyelesaian masalah dan melengkapi hasil pekerjaannya.Subjek 1 mampu memeriksa kembali kelengkapan masalah kelengkapan setiap langkah pengerjaan dengan menyesuaikan hasil berdasarkan permasalahan dan menginterprestasikan hasil temuannya. Pada nomor 1 Subjek 1 mampu membuat kesimpulan dari permasalahan dengan benar, namun pada nomor 2 siswa kurang teliti sehingga lupa menuliskan kesimpulan dari hasil temuannya.

\section{Subjek 2 (Kategori Kemampuan Tinggi)}

Pada tahap memahami masalah subjek 2 mampu menerjemahkan dan mengidentifikasi bagian terpenting dalam permasalahan yaitu menentukan apa yang diketahui dan apa yang ditanyakan dalam permasalahan dengan benar. Dalam mengidentifikasi masalah Subjek 2 mampu mengetahui dan menyebutkan benda yang diketahui dari soal.Subjek 2 juga menjelaskan benda yang ada dalam soal dijadikan sebagai variabel.Sehingga Subjek termasuk golongan dapat mengenal bentuk dan menerjemahkan kalimat/masalah sistem persamaan linear dua variabel dengan benar. 
Pada tahap perencanaan, Subjek 2 mampu merencanakan pemecahan masalah secara runtut dengan menuliskan setiap langkah penyelesaian yaitu diketahui, ditanya dan dijawab.Dalam memecahkan masalah Subjek 2 merencanakan menggunakan metode penyelesaian eliminasi dan substitusi.

Pada tahap pelaksanaan, Subjek 2 mampu melaksanakan setiap langkah penyelesaian sesuai dengan apa yang direncanakan. Subjek 2 melaksanakan langkah awal dengan menuliskan apa yang diketahui dan apa yang ditanyakan dari soal. Kemudian dilanjutkan dengan menuliskan permisalan dan model matematika dari permasalahan.Dalam melakukan perhitungan Subjek 2 mampu mengoperasikan penyelesaian menggunakan eliminasi dan substitusi.Sehingga dapat menentukan nilai $\mathrm{x}$ dan nilai $\mathrm{y}$ dengan benar.

Pada tahap melihat kembali, Subjek 2 menuliskan penyelesaian masalah dan melengkapi hasil pekerjaannya.Subjek 2 mampu memeriksa kembali kelengkapan masalah kelengkapan setiap langkah pengerjaan dengan menyesuaikan hasil berdasarkan permasalahan dan menginterprestasikan hasil temuannya.Subjek 2 juga mampu membuat kesimpulan dari hasil temuannya dengan benar.Hal ini dapat menjelaskan bahwa Subjek 2 pada setiap langkah pengerjaannya terampil dan teliti dalam menggunakan kemampuan mengolah angka serta mampu dalam menghubungkan antar konsep.

\section{Subjek 3 (Kategori Kemampuan Sedang)}

Pada tahap memahami masalah subjek 3 mampu menerjemahkan dan mengidentifikasi bagian terpenting dalam permasalahan yaitu menentukan apa yang diketahui dan apa yang ditanyakan dalam permasalahan dengan benar. Dalam mengidentifikasi masalah Subjek 3 mampu mengetahui dan menyebutkan benda yang diketahui dari soal.Subjek 3 juga menjelaskan benda yang ada dalam soal dijadikan sebagai variabel.Sehingga Subjek termasuk golongan dapat mengenal bentuk dan menerjemahkan kalimat/masalah sistem persamaan linear dua variabel dengan benar.

Pada tahap perencanaan, Subjek 3 mampu merencanakan pemecahan masalah secara runtut dengan menuliskan setiap langkah penyelesaian yaitu diketahui, ditanya dan dijawab.Dalam memecahkan masalah Subjek 3 merencanakan menggunakan metode penyelesaian eliminasi dan substitusi.

Pada tahap pelaksanaan, Subjek 3 mampu melaksanakan setiap langkah penyelesaian sesuai dengan apa yang direncanakan. Subjek 3 melaksanakan langkah awal dengan menuliskan apa yang diketahui dan apa yang ditanyakan dari soal. Kemudian dilanjutkan dengan menuliskan permisalan dan model matematika dari permasalahan.Dalam melakukan perhitungan Subjek 3 pada 
nomor 1 mampu mengoperasikan penyelesaian menggunakan eliminasi dan substitusi. Namun Subjek 3 belum tepat dalam mengoperasikan cara eliminasi dan substitusi tersebut.

Pada tahap melihat kembali, Subjek 3 menuliskan penyelesaian masalah dan melengkapi hasil pekerjaannya.Subjek 3 mampu memeriksa kembali kelengkapan masalah kelengkapan setiap langkah pengerjaan dengan menyesuaikan hasil berdasarkan permasalahan dan menginterprestasikan hasil temuannya. Subjek 3 juga mampu membuat kesimpulan dari hasil temuannya pada nomor 1 dengan benar tetapi Subjek 3 belum mampu menuliskan kesimpulan dari hasil temuannya karena subjek tidak melanjutkan pekerjaannya.

\section{Subjek 4 (Kategori Kemampuan Sedang)}

Pada tahap memahami masalah Subjek 4 mampu menerjemahkan dan mengidentifikasi bagian terpenting dalam permasalahan yaitu menentukan apa yang diketahui dan apa yang ditanyakan dalam permasalahan dengan benar. Dalam mengidentifikasi masalah Subjek 4 mampu mengetahui dan menyebutkan benda yang diketahui dari soal.Subjek 4 juga menjelaskan benda yang ada dalam soal dijadikan sebagai variabel.Sehingga Subjek termasuk golongan dapat mengenal bentuk dan menerjemahkan kalimat/masalah sistem persamaan linear dua variabel dengan benar.

Pada tahap perencanaan, Subjek 4 mampu merencanakan pemecahan masalah secara runtut dengan menuliskan setiap langkah penyelesaian yaitu diketahui, ditanya dan dijawab.Dalam memecahkan masalah Subjek 4 merencanakan menggunakan metode penyelesaian eliminasi dan substitusi.

Pada tahap pelaksanaan, Subjek 4 mampu melaksanakan setiap langkah penyelesaian sesuai dengan apa yang direncanakan. Subjek 4 melaksanakan langkah awal dengan menuliskan apa yang diketahui dan apa yang ditanyakan dari soal. Kemudian dilanjutkan dengan menuliskan permisalan dan model matematika dari permasalahan.Dalam melakukan perhitungan Subjek 4 pada nomor 1 mampu mengoperasikan penyelesaian menggunakan eliminasi dan substitusi. Namun Subjek 4 belum tepat dalam mengoperasikan substitusi pada nomor 2 tersebut.

Pada tahap melihat kembali, Subjek 4 menuliskan penyelesaian masalah dan melengkapi hasil pekerjaannya.Subjek 4 mampu memeriksa kembali kelengkapan masalah kelengkapan setiap langkah pengerjaan dengan menyesuaikan hasil berdasarkan permasalahan dan menginterprestasikan hasil temuannya. Subjek 4 juga mampu membuat kesimpulan dari hasil temuannya 
pada nomor 1 dengan benar tetapi Subjek 4 belum mampu menuliskan kesimpulan dari hasil temuannya pada nomor 2 dengan benar karena Subjek 4 belum tepat dalam mengoperasikan cara substitusi.

\section{Subjek 5 (Kategori Kemampuan Rendah)}

Pada tahap memahami masalah Subjek 5 mampu menerjemahkan dan mengidentifikasi bagian terpenting dalam permasalahan yaitu menentukan apa yang diketahui dan apa yang ditanyakan dalam permasalahan dengan benar. Dalam mengidentifikasi masalah Subjek 5 belum tepat dalam menyebutkan benda yang diketahui dari soal.Sehingga Subjek termasuk golongan yang belum dapat mengenal bentuk dan menerjemahkan kalimat/masalah sistem persamaan linear dua variabel dengan benar.

Pada tahap perencanaan, Subjek 5 mampu merencanakan pemecahan masalah secara runtut dengan menuliskan setiap langkah penyelesaian yaitu diketahui, ditanya dan dijawab.Dalam memecahkan masalah Subjek 5 merencanakan menggunakan metode penyelesaian eliminasi dan substitusi.

Pada tahap pelaksanaan, Subjek belum mampu melaksanakan setiap langkah penyelesaian sesuai dengan apa yang direncanakan. Subjek 5 melaksanakan langkah awal dengan menuliskan apa yang diketahui dan apa yang ditanyakan dari soal. Kemudian dilanjutkan dengan menuliskan permisalan dan model matematika dari permasalahan. Subjek 6 dalam memisalkan belum tepat menjelaskan apa yang seharusnya dijadikan variabel. Dalam melakukan perhitungan Subjek 5 belum mampu mengoperasikan penyelesaian menggunakan eliminasi dan substitusi sesuai dengan yang direncanakan.

Pada tahap melihat kembali, Subjek 5 belum mampu memeriksa kembali kelengkapan masalah setiap langkah.Subjek 5 juga belum mampu membuat kesimpulan dari hasil temuannya pada dengan benar.

\section{Subjek 6 (Kategori Kemampuan Rendah)}

Pada tahap memahami masalah Subjek 6 mampu menerjemahkan dan mengidentifikasi bagian terpenting dalam permasalahan yaitu menentukan apa yang diketahui dan apa yang ditanyakan dalam permasalahan dengan benar. Dalam mengidentifikasi masalah Subjek 6 belum tepat dalam menyebutkan benda yang diketahui dari soal.Sehingga Subjek termasuk golongan yang belum dapat mengenal bentuk dan menerjemahkan kalimat/masalah sistem persamaan linear dua variabel dengan benar. 
Pada tahap perencanaan, Subjek 6 mampu merencanakan pemecahan masalah secara runtut dengan menuliskan setiap langkah penyelesaian yaitu diketahui, ditanya dan dijawab.Dalam memecahkan masalah Subjek 6 merencanakan menggunakan metode penyelesaian eliminasi dan substitusi.

Pada tahap pelaksanaan, Subjek belum mampu melaksanakan setiap langkah penyelesaian sesuai dengan apa yang direncanakan. Subjek 6 melaksanakan langkah awal dengan menuliskan apa yang diketahui dan apa yang ditanyakan dari soal. Kemudian dilanjutkan dengan menuliskan permisalan dan model matematika dari permasalahan. Subjek 6 dalam memisalkan belum tepat menjelaskan apa yang seharusnya dijadikan variabel. Dalam melakukan perhitungan Subjek 6 belum mampu mengoperasikan penyelesaian menggunakan eliminasi dan substitusi sesuai dengan yang direncanakan.

Pada tahap melihat kembali, Subjek 6 belum mampu memeriksa kembali kelengkapan masalah setiap langkah.Subjek 6 juga belum mampu membuat kesimpulan dari hasil temuannya pada dengan benar. 


\section{DAFTAR PUSTAKA}

Polya, G. (1937). How To Solve It. America: Princeton University Press.

Suardi, M. (2012). Pengantar Pendidikan Teori dan Aplikasi. Jakarta Barat: PT Indeks. 